\title{
ALTERNATYWNA MIARA WIELKOŚCI? POSTKOLONIALNE UWARUNKOWANIA WIZJI HEGEMONICZNEJ PRZESZLOŚCI POLSKI W WYBRANYCH HISTORIACH ALTERNATYWNYCH
}

\author{
NATALIA LEMANN ${ }^{1}$ \\ (Uniwersytet Łódzki)
}

\begin{abstract}
Słowa kluczowe: postkolonializm, dyskursy postzależnościowe, literatura, necessary fictions, historia alternatywna, melancholijny dyskurs minionej wielkości
\end{abstract}

Key words: postcolonialism, post-dependence discourses, literature, necessary fictions, alternate history, melancholic discourse of former glorious past

\begin{abstract}
Abstrakt: Natalia Lemann, ALTERNATYWNA MIARA WIELKOŚCI? POSTKOLONIALNE UWARUNKOWANIA WIZJI HEGEMONICZNEJ PRZESZŁOŚCI POLSKI W WYBRANYCH HISTORIACH ALTERNATYWNYCH. „PORÓWNANIA” 14, 2014, T. XIV, s. 19-41. ISSN 1733165X. Celem artykułu jest wykazanie, jak duże znaczenie dla zrozumienia specyfiki polskich historii alternatywnych mają uwarunkowania postkolonialne. Jednym z najważniejszych następstw postkolonializmu jest specyficzna zaniżona samoświadomość subalterna, prowadząca w konsekwencji do kompleksu niższości narodu podporządkowanego. Co więcej, „postkolonialny stan świadomości" trwa nawet po ustaniu procesu politycznego podporządkowania. Paradoksalnie jednak, kompleks niższości może objawiać się w pielęgnowaniu melancholijnych wyobrażeń o wspaniałej, pełnej chwały przeszłości. Takie wyobrażenia manifestują się między innymi w literaturze, która jest przecież sposobem mapowania świata i opisywania jego kulturowej różnorodności. W tym ujęciu literatura staje się zwierciadłem ideologii i polityki. Interesującym przykładem kreowania obrazów minionej hegemonii historycznej są powieści z gatunku historii alternatywnej. Dlatego też, autorka, korzystając z terminów H. Bhabhy "pisanie narodu”, „pedagogika narodowa” czy "necessary fictions”, opisuje i analizuje sposoby w jakie wybrane historie alternatywne wypełniają marzenia subalterna o minionej wielkości politycznej. Utwory literackie Marcina Wolskiego (Alterland, Mocarstwo, Jedna przegrana bitwa), Andrzeja Ziemiańskiego (Bomba Heisenberga), Dariusza Spychalskiego (Krzyżacki poker), Macieja Parowskiego (Bu-
\end{abstract}

${ }^{1}$ Correspondence Address: natalialemann@uni.lodz.pl 
rza. Ucieczka z Warszawy '40) oraz prace z gatunku dziennikarskiej niefikcjonalnej pop-historii (np. Pakt Ribbentrop-Beck, czyli jak Polacy mogli u boku III Rzeszy pokonać Zwiazek Sowiecki Piotra Zychowicza) kreują fikcyjne, alternatywne światy, w których Polacy podbili znaczną część świata, pokonali wrogów podczas II wojny światowej oraz podporządkowali sobie ZSRR i mniejsze sąsiadujące narody. Wspomniane powyżej utwory literackie stanowią dla subalterna "konieczne fikcje" [necessary fictions], stanowiące rodzaj autoterapii. To zaś może być rozumiane jako efekt resentymentów czy postkolonialnej, nieprzepracowanej przez subalterna traumy.

Abstract: Natalia Lemann, AN ALTERNATIVE MEASURE OF GREATNESS? - POSTCOLONIAL DETERMINANTS OF THE POLISH HEGEMONIC VISIONS OF HISTORY IN SELECTED ALTERNATIVE HISTORY NOVELS. „PORÓWNANIA” 14, 2014, Vol. XIV, p. 19-41. ISSN 1733165X. The aim of this paper is to show the significance of the postcolonial determinants for understanding the specificity of the Polish alternate history novels. The author argues that one of the most meaningful repercussions of postcolonialism is the specific self-consciousness of the insignificant subalterns and, as a consequence, the inferiority complex. More importantly, the "subaltern state of mind" lasts even after the postcolonial subordination ends. Paradoxically, the inferiority complex could be manifested as a belief in one's glorious and magnified past. Such a conviction is evoked inter alia by literature, which is a type of mapping the world and describing cultural diversity. In this scope, literature is a mirror of ideology and policy. Alternate history novels are interesting examples of creating a false magnificent past. Therefore, applying the terms such as „writing the nation", "national pedagogy" and "necessary fictions" (H. Bhabha) the author discusses the capability of the selected alternate history novels for fulfilling the subalterns' dreams about greatness, power and political importance. The literary works of Marcin Wolski (Alterland, Mocarstwo, Jedna przegrana bitwa), Andrzej Ziemiański (Bomba Heisenberga), Dariusz Spychalski (Krzyżacki poker), Maciej Parowski (Burza. Ucieczka z Warszawy '40) and the journalistic, non-fictional products of pop-history, such as Pakt Ribbentrop-Beck, czyli jak Polacy mogli u boku III Rzeszy pokonać Zwiazek Sowiecki by Piotr Zychowicz, describe fictional, alternates, worlds in which Poland conquered a significant part of the world, defeated their enemies in the Second World War and subordinated the Soviet Union as well as smaller neighbours. Thence, the above mentioned authors give the subalterns the necessary fiction, a kind of self-therapy. The latter could be also understood, the author concludes, as the effect of postcolonial trauma, resentments and unresolved issues stemming from subjugation.

Jednym z najdłużej trwających następstw sytuacji skolonizowania jest kompleks niższości narodu podporządkowanego. Paradoksalnie jednak, efekty kompleksu niższości mogą przybierać postać nie tylko kolektywnej „choroby duszy tych populacji, które $\mathrm{w}$ następstwie skolonizowania postrzegają siebie jako bezsilne, czy zacofane" ${ }^{2}$, czy wiktimofili ${ }^{3}$ ale i równie chorobliwego uporczywie poszu-

2 D. Skórczewski, Melancholia dyskursu kresoznawczego. W: Teoria - literatura-dyskurs. Pejzaż postkolonialny. Lublin 2013, s. 428. 
kiwanego/kreowanego poczucia wyższości. Hanna Gosk pisze, że objawia się to m.in. jako

upodobanie do spoglądania wstecz, ku suwerennej przeszłości, w której da się wykazać momenty chwały, gdy teraźniejszość cierpi na ich niedosyt. Albo niezwykły wprost wysiłek interpretacyjny $\mathrm{w}$ realiach polskich, począwszy od XIX wieku, wkładany z rewaluację licznych porażek na polu militarnym, politycznym, by nie wspomnieć o gospodarczym czy ogólno-cywilizacyjnym i dowartościowujący trud prze-pisania narracji im poświęconej $(\ldots)^{4}$.

Oswobodzony z sytuacji zależności ${ }^{5}$, niedawny subaltern stara się scalić swą pokaleczoną tożsamość między innymi w oparciu o melancholijne dyskursy minionej wielkości, powrotu do ery złotego wieku politycznej suwerenności i kulturowej, esencjalnie pojmowanej, odrębności i wyjątkowości. Polski „postkolonialny powrót do historii" 6 przyjmuje postać nie tylko literatury pisanej w trybie „ku pokrzepieniu serc", ale i oznacza często zwrot do idei wielkiej mocarstwowej Polski - piastowskiej, jagiellońskiej, sarmatyzmu ${ }^{7}$, idei federacyjnej Rzeczpospolitej (Wielu) Narodów. Taki nostalgiczny, lokujący ideał w przeszłości ${ }^{8}$, pozornie sielski, choć $\mathrm{w}$ istocie opresyjny obraz - bo niedawna ofiara ma tendencje do łatwego, wspartego "moralnym prawem”, przekształcania się w opresora i zajęcia jego miejsca ${ }^{9}$ - wspiera dość często zjawiska takie jak: natywizm, etnocentryzm, szowinizm czy ksenofobia, pojawiające się jako forma najprostszego odreagowania10.

Słowo "nostalgia", charakteryzujące takie narracje, utworzył w 1688 roku bazylejski lekarz Johannesa Hopfer ze słów greckich „nosteo” i „algos”. Oznacza ono „bolesne pragnienie powrotu”, choć w języku greckim nosteo oznaczało "powrócić”, „ocaleć", a nie „ból”. Grecki źródłosłów nostalgii można więc ustalić jako

${ }^{3}$ R. Nycz, Wprowadzenie. "Nie leczony, chroniczny pogłos". Trzy uwagi o polskim dyskursie postzależnościowym. W: Kultura po przejściach, osoby z przeszłością. Polski dyskurs postzależnościowy - konteksty i perspektywy badawcze. Red. R. Nycz. Kraków 2011, s. 11.

${ }^{4} \mathrm{H}$. Gosk, Opowieści "skolonizowanego/kolonizatora". W kręgu studiów postzależnościowych na literatura polską w XX i XXI wieku. Kraków 2010, s. 18-19.

${ }^{5} \mathrm{Wg}$ H. Gosk złożoną sytuację postkolonialną Polski lepiej oddaje termin postzależność, bo określa sytuację podmiotu przez długi czas pozostającego w sytuacji uzależnienia a następnie, po ustaniu owej zależności, chcącego ów stan rzeczy zmienić i odreagować: H. Gosk, Opowieści „skolonizowanego/kolonizatora", op. cit.

${ }^{6}$ D. Skórczewski, Melancholia dyskursu kreso znawczego. W: Teoria - literatura - dyskurs, op. cit., s. 437.

7 Por. E. Thompson, Sarmatyzm i postkolonializm. „Dziennik. Europa” 2006, nr 137, s. 11; Nowoczesność $i$ sarmatyzm. Red. P. Czapliński. Poznań 2011; K. Jaskółowski, Wytwórnie sarmatyzmu. „Przegląd Polityczny" 2012, nr 11, s. 90-95.

${ }^{8}$ M. Zaleski, Formy pamięci. O przedstawianiu przeszłości w polskiej literaturze wspótczesnej. Warszawa 1996, s. 11; P. Czapliński, Wznioste tęsknoty; nostalgia w prozie lat dziewięćdziesiątych. Kraków 2001.

${ }^{9}$ F. Fanon, Wyklęty lud ziemi. Przeł. H. Tygielska. Przedm. E. Rekłajtis. Posł. J.-P. Sartre. Warszawa 1985, s. 22.

${ }^{10}$ D. Skórczewski, Tożsamość w ujęciu postkolonialnym. W: Teoria - literatura - dyskurs, op. cit., s. 146. 
"ocalający powrót"11. Wypada jednak postawić pytanie, czy taki nostalgiczny powrót do przeszłości naprawdę ocala, czy też stanowi raczej szeroko otwarte wrota dla resentymentu12, cechy ludzi słabych i niepewnych swego miejsca na ziemi, skłonnych do poczucia cierpiętnictwa, pielęgnujących status ofiary. Ryszard $\mathrm{Nycz}$ powiada, iż nostalgiczne lokowanie się wobec przeszłości sprawia, że przyszłość jest niemożliwa, bo jest jedynie „post-przeszłością"13, odcięcie wszelkich drzwi do przyszłości przynosi niezahamowany powrót stłumionego, wpartego, wstydliwego. To zaś prowadzi do nienawiści, która jest „afektem podporządkowanych, uzależnionych", skoro pojawia się „jako resentyment, uczucie wtórne wobec klęski, przeżycia, wstydu upokorzenia ${ }^{14 "}$. Ryszard Nycz wyraził rzecz metaforycznie, mówiąc iż wciąż „dosięga nas długa ręka przeszłości”15. Nostalgia jest zatem niebezpieczna:

Ze wszystkich sposobów posługiwania się historią nostalgia jest najpopularniejsza i wygląda najbardziej niewinnie i jest zapewne najbardziej niebezpieczna.... Chory człowiek Europy tęskni za dzieciństwem, którego nigdy nie miał, rojąc o przeszłości, która naprawdę nie istniała ${ }^{16}$.

W procesie pisania (postzależnościowego) narodu ${ }^{17}$, przepracowywania przez niego swej własnej historii, bezustannego pozycjonowania się $\mathrm{w}$ stosunku do tradycji i lokowania wobec niej zamierzeń i marzeń, owe negatywne inkluzywne stanowiska są tylko jedną ze strategii, etapem (koniecznym) bezustannie trwającej "semiozy przeszłości" - procesem nadawania znaczeń mitom, zdarzeniom, postaciom, włączania ich $\mathrm{w}$ narracje reinterpretujące, posiadające dla zbiorowości w danym momencie historycznym status i wartość prawdy"18. Literatura, stanowiąca kluczowy element „pedagogiki narodowej"19, nie stanowi monolitu, przeciwnie, otwarta jest na wszelkie formy sygnifikacji i ewokacji przeszłości i hybry-

${ }^{11}$ Za P. Czapliński, Wzniosłe tęsknoty..., op. cit., s. 6-7.

12 E. Thompson przypomniała pojmowanie resentymentu przez F. Nietzschego: E. Thompson, Sarmatyzm i postkolonializm, op. cit., s. 11.

${ }^{13}$ R. Nycz, Wprowadzenie. „Nie leczony, chroniczny pogłos", op. cit., s. 11.

$14 \mathrm{P}$. Tomczok, Nienawiść jako afekt zależności i postzależności w powieści historycznej. W: (P)O zaborach, (P)O wojnie, (P)O PRL. Polski dyskurs postzależnościowy dawniej i dziś. Red. H. Gosk i E. Kraskowska. Kraków 2013, s. 513.

${ }^{15}$ R. Nycz, Wprowadzenie. „Nie leczony, chroniczny pogłos". W: Kultura po przejściach. Osoby z przeszłościa, op. cit., s. 11.

${ }^{16}$ M. Chase, Ch. Shaw, The Dimensions of Nostalgia. W: M. Chase, Ch. Shaw, The Imagined Past, s. 1; za: M. Zaleski, Formy pamięci..., op. cit., s. 20.

17 „Pisanie narodu” to termin H. Bhabhy, DyssemiNacja. W: Miejsca kultury. Przeł. T. Dobrogoszcz. Kraków 2010, s. 153.

18 A. D. Smith, Etniczne źródła narodów. Przeł. M. Głowacka-Grajper. Kraków 2009; D. Skórczewski, Tożsamość w ujęciu postkolonialnym. W: Teoria - literatura - dyskurs, op. cit., s. 124.

${ }^{19}$ Termin. H. Bhabhy, DyssemiNacja, op. cit., s. 153-155. 
dyczności kulturowej, a także podejścia do postzależnościowej przeszłości. Pedagogika narodowa ma jednak charakter pragmatyczny, operacyjny, bo spełnia funkcje "służebne w stosunku do rozpoznanych i wyartykułowanych postkolonialnym idiomem potrzeb populacji ${ }^{20 "}$.

Mając świadomość złożoności procesu lokowania się wobec postzależnościowej historii oraz wielości towarzyszących temu procesowi strategii, postanowiłam przyjrzeć się obecnie niezmiernie popularnemu gatunkowi historii alternatywnych. Gatunek ten przynależy do prozy spekulatywnej, z pewnym uproszczeniem en bloc lokowany jest $\mathrm{w}$ obrębie szeroko pojętej literatury fantastycznej. Historie alternatywne kreują światy, w których wydarzenia historyczne miały przebieg odmienny niż ten znany ze świata rzeczywistego ${ }^{21}$ Truizm, iż literatura, jako znaczący element kulturowej areny, na której bezustannie ścierają się wielorakie i sprzeczne interesy, jest zawsze polityczna ${ }^{22}$, nabiera w odniesieniu do historii alternatywnych szczególnej mocy. Porzucenie powszechnie znanego przebiegu dziejów nie jest przecież zabiegiem niewinnym światopoglądowo i aksjologicznie, a wymyślanie alternatywnych scenariuszy historii jest objawem roszczenia przez autora pewnych pretensji do przeszłości. Kształt historii alternatywnej zawsze jest

${ }^{20}$ D. Skórczewski, Drogi i rozdroża studiów postkolonialnych w Polsce. W: Teoria - Literatura - Dyskurs, op. cit., s. 101.

${ }^{21}$ Por. G. D. Rosenfeld, The World Hitler Never Made. Cambridge 2005; K. Hellekson Karen, The Alternate History. Refiguring Historical Time. Ohio\&London 2001; Virtual History: Alternatives and Counterfactauls. Ed. N. Ferguson. New York 1997; C. Gallagher, Dlaczego opowiadamy jak nie byto? Przeł. T. Bilczewski, A. Kowalcze-Pawlik. „Teksty Drugie” 2012, nr 1-2, s. 138-152; R. Bień, Polska proza z gatunku historii alternatywnej w obliczu przemian po roku 1989. W: Inna literatura? Dwudziestolecie 1989-2009, t. 1. Red. Z. Andres, J. Pasterski. Rzeszów 2010, s. 189-199; N. Lemann, Historia alternatywna. W: Stownik rodzajów i gatunków literackich. Red. G. Gazda. Warszawa 2012, s. 380-388; eadem, PODobni NiePODobni. „Muza dalekich podróży” Teodora Parnickiego i "Lód” Jacka Dukaja jako przykład dwóch sposobów relatywizacji historii. „Porównania” 2012, nr 10, s. 173-188; eadem, Czy można uchronić się od przeszłości? historie alternatywne i uchronie jako literackie aporie polityki i wiedzy historycznej. „Zagadnienia Rodzajów Literackich" 2011, nr 2, s. 339-356; eadem, PODobna historia, czyli rzecz o historii alternatywnej i jej miejscu we wspótczesnej historiografii i literaturoznawstwie. W: Exploring the Benefits of the Alternate History Genre / W poszukiwaniu pożyteczności gatunkuhistorii alternatywnych. Red. Z. Wąsik, M. Oziewicz, J. Deszcz-Tryhubczak. „Philologica Wratislaviensia: Acta et Studia” 2011 nr 5, s. 21-38; eadem, Czy historia może być skandalem? Rzecz o historiach alternatywnych $i$ ich sporach z przeszłościa/teraźniejszościa. W: Skandal w kulturze europejskiej i amerykańskiej, Seria: Tabu - Trend - Transgresja, t. 1. Red. B. PłonkaSyroka, M. Dąbrowska, J. Nadolna, M. Skibińska. Warszawa 2013, s. 123-138.

22 Por. E. Said, Orientalizm. Przeł. W. Kalinowski. Wstęp Z. Żygulski jun. Warszawa 1991; idem, Kultura i imperializm. Przeł. M. Wyrwas-Wiśniewska. Kraków 2009; C. Gallagher, S. Greenblatt, Practicing New Historicism. Chicago 2000; S. Greenblatt, Czym jest historia literatury? Przeł. K. Kwapisz. „Teksty Drugie" 2005, nr 1-2; S. Greenblatt, Poetyka kulturowa. Pisma wybrane. Przeł. K. Kujawińska-Courtney. Kraków 2006; M. Foucault, Nadzorować i karać. Narodziny więzienia. Przeł. T. Komendant. Warszawa 1993; J. Rancière, Estetyka jako polityka, ze wstępem A. Żmijewskiego i posłowiem S. Žižka. Przeł. J. Kutyła i P. Moscicki. Warszawa 2007; J. Ranciére, Na brzegach politycznego. Przeł. J. Sowa. Kraków 2008; F. Jameson, The Political Uncouncious. Narrative as a Socially Symbolic Act. London 1981. 
więc wypadkową teraźniejszości i poglądów polityczno-historycznych autora i jako taki często realizuje resentymentalny i życzeniowy stosunek do świata i przeszłości. Historia znana ze świata aktualnego jest w tym ujęciu, chora, traumatyczna, zaś alternatywne scenariusze stanowią próbę jej leczenia. Oczywiście, ten silnie zróżnicowany, niejednorodny gatunek literacki zawiera bardzo różne sposoby ewokowania postkolonialnej przeszłości i tradycji narodowej. Znajdziemy niezwykle interesujące próby dekonstrukcji narodowych mitów i tradycji (por. Teodor Parnicki, Muza dalekich podróży23; Szczepan Twardoch, Wieczny Grunwald, Powieść zza końca czasów24; J. Dukaj, Xavras Wyżryn i inne fikcje narodowe25; Lód26; W. Szostak, Dumanowski27; Fuga28; K. T. Lewandowski, Orzet bielszy niż gołębica29; Ł. Orbitowski, Ogień. Widowisko historyczno-fantastyczne $e^{30}$, A. Przechrzta, Gambit Wielopolskiego ${ }^{31}$; E. Redliński, Krfotok ${ }^{32}$ i wiele innych) ale i szeroką reprezentację scenariuszy realizujących potrzeby tęsknoty za hegemoniczną, wspaniałą przeszłością. Upraszczając nieco, powiedzieć można, że w polskich historiach alternatywnych konkurują dwa nurty i dwie wizje: ironiczno-obrazoburczy i hegemoniczny, tradycjonalistyczny.

Na potrzeby tego artykułu zanalizuję jedynie wybrane realizacje tego drugiego nurtu, gdyż powieści takie stanowią, moim zdaniem, niezmiernie interesujący przykład działania resentymentu, chorobliwej melancholii, wreszcie zaś - czytelny znak tego, że trauma postkolonialna nie została w Polsce przepracowana. Literackie obrazy Polski jako kraju potężnego, wciąż dominującego na mapie Europy, skazanego na wielkość, są niczym innym, jak działaniem kolonialnej mimikry, powtórzeniem znienawidzonej sytuacji uzależnienia "terapeutyczną" dawką zemsty. Ów świat à rebours jest ironicznym rewersem czasów zależności, wspomnianej już powyżej chęci zajęcia miejsca kolonizatora. Bogusław Bakuła, diagnozując polski stan postzależnościowy, dokonał interesującego porównania. Podczas gdy dla Ukrainy dominującym modelem dyskursu postzależnościowego jest podkreślanie tożsamości kulturowej budowanej w opozycji do Rosji, to w Polsce kluczową rolę odgrywa "demaskowanie symbolicznych, narodowych tęsknot neokolonialnych ${ }^{33 \prime}$. Niniejszy artykuł może więc zostać potraktowany jako element

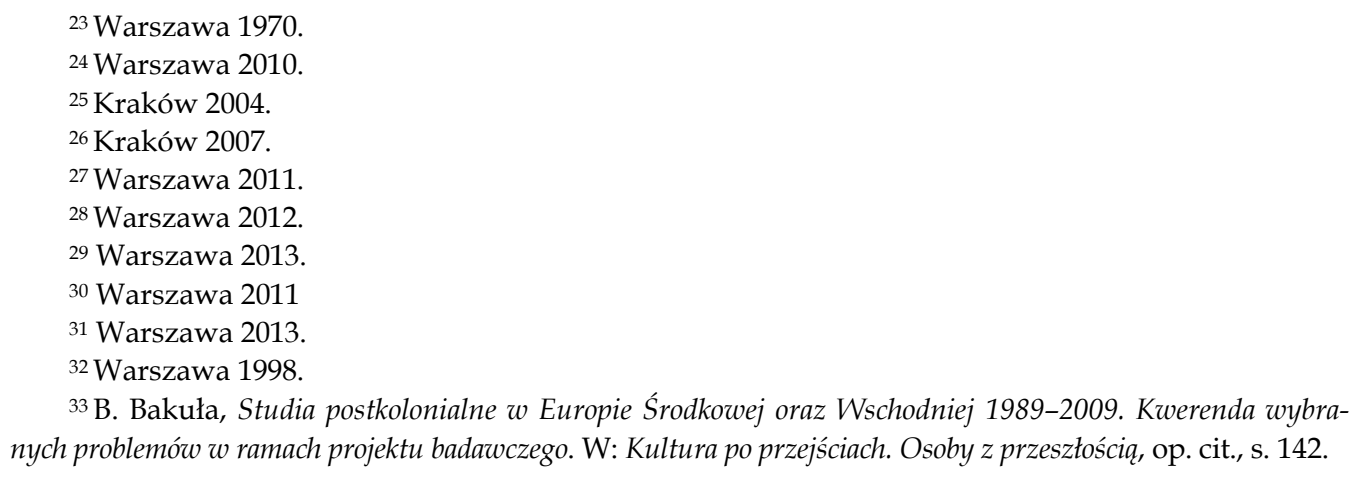

${ }_{33}$ B. Bakuła, Studia postkolonialne w Europie Środkowej oraz Wschodniej 1989-2009. Kwerenda wybranych problemów w ramach projektu badawczego. W: Kultura po przejściach. Osoby z przeszłościa, op. cit., s. 142. 
obnażania owych neokolonialnych tęsknot, znajdujących swą literacką reprezentację w niektórych historiach alternatywnych. Wydaje się, że gatunek ten jest znakomitym materiałem badawczym, albowiem kreowanie nieistniejących realnie alternatywnych światów historycznych pozwala na zniesienie, lub przynajmniej znaczne nadwątlenie, autocenzury, występującej w utworach realistycznych. Swobodna gra wyobraźni pozwala bez większych wyrzutów sumienia, tudzież bez cenzorskich nożyc superego, rozsnuwać marzenia i budować pełne rozmachu i chwały scenariusze. Na emocjonalny charakter historii alternatywnych zwracał uwagę Aleksander Demandt, pisząc, iż „tego rodzaju idealne bądź przerażające wizje zaspokajają albo naszą potrzebę sensacji albo pocieszenia. To jednak osłabia nasz krytycyzm i zafałszowuje ocenę prawdopodobieństwa"34. Jeremy Black, teoretyk kontrfaktualizmu w historii przypomina, że kluczowe pytanie "co jeśli" zbyt łatwo ulega przekształceniu w "gdyby tylko"35. Przemysław Czapliński trafnie natomiast zauważył, że „Niezależność po okresie podległości jest mierzona potrzebami fantazmatycznymi, a nie pragmatycznymi ${ }^{36 "}$, a w historiach alternatywnych owa fantazmatyczność ulega swoistemu podwojeniu i wzmocnieniu. Historie alternatywne niejednokrotnie zostają instytucjonalnie wprzęgnięte $\mathrm{w}$ działalność dydaktyczną i popularyzatorską historii, nieraz równocześnie z byciem jednym z narzędzi tzw. polityki historycznej37, czyli, zgodnie z definicją Marka Cichockiego, jednego z promotorów terminu, „wzmocnieniu publicznego dyskursu o przeszłości, poprzez różne formy jego instytucjonalizacji”38. Dariusz Gawin politykę historyczną określił jako „instrument afirmacji zbiorowej tożsamości (w tym przede wszystkim wspólnej przeszłości)"39. Znaczący jest tutaj obecnie 11-tomowy cykl powieściowy pt. Zwrotnice czasu wydawany przez Narodowe Centrum Kultury. Wartość edukacyjna owych powieści jest nie do przecenienia, jednak widać że NCK stara się wprzęgnąć ów cykl w ramy pedagogiki narodowej, czy budowania aktualnie pożądanej wizji przeszłości. Analiza wstępów do kolejnych powieści pióra dyrektora Narodowego Centrum Kultury, Krzysztofa Dudka, dowodzi rangi, jaką ów cykl zajmuje w edukacyjnych projektach NCK. Przedmowy te każdorazowo starają się osadzić zapowiadaną powieść w cyklu upamiętniana heroicznej bądź martyrologicznej przeszłości, nawet jeśli konkretny tekst (tj. Wieczny Grun-

${ }^{34}$ A. Demandt, Historia niebyła. Co by było, gdyby...? Przeł. M. Skalska. Warszawa 1999, s. 138.

${ }^{35}$ J. Black, What If? Counterfactualism and the Problem of History. London 2008, s. 5.

${ }^{36}$ P. Czaplińki, Jezzyki niezależności. Jak jest artykułowana w literaturze niepodległość odzyskana przez Polskę w roku 1989? W: Kultura po przejściach. Osoby z przeszłościa, op. cit., s. 42.

37 Por. Polityka historyczna: historycy-politycy-prasa. Konferencja pod honorowym patronatem Jana Nowaka-Jeziorańskiego. Red. A. Cichocka, A. Panecka. Warszawa 2005; D. Gawin, Polityka historyczna - próba bilansu. „Arkana” 2009, nr 6 (90), cyt. za: http://www.teologiapolityczna.pl/dariusz-gawin-politykahistoryczna-proba-bilansu-arcana-nr-90-\#p,1 (data dostępu: 30.12.2011).

38 Polityka historyczna za i przeciw. „Mówią Wieki” 2006, nr 8, s. 11.

39 D. Gawin, Wspólnota przeszłości, „Rzeczpospolita” 2006, nr z dn. 7 października. Cyt za: http:/ / www.teologiapolityczna.pl/gawin_06_10_wspolnota_przeszlosci (data dostępu: 30.12.2011). 
wald S. Twardocha, Orzeł bielszy niż gotębica K. T. Lewandowskiego, czy Ogień Ł. Orbitowskiego) pozostają z nią w ironicznej, rażącej sprzeczności, eksplorując ścieżkę dekonstrukcji polskich mitów mesjanistycznych. Tomasz Merta uznał, że po 1989 r. nadmiernie eksponowano mroczne strony naszej historii, zaniedbując promocję tych pięknych, jasnych, bohaterskich ${ }^{40}$, tak iż zdaniem Gawina:

Postawa heroicznego, radykalnie etycznego krytycyzmu zaczęła wychowywać coraz szersze rzesze inteligencji do krytycyzmu automatycznego, mimowolnego. [...] Radykalny krytycyzm stał się intelektualnym nałogiem, mentalną dyspozycją wyprzedzającą wszelkie myślenie. Już nie tylko zwalczano szkodliwe mity i fałszywe wyobrażenia, lecz z czasem atak skierowano także przeciwko każdemu zespołowi przekonań uznawanych za mity, wręcz każdemu zbiorowemu wyobrażeniu. Z ustaleń poczynionych w trakcie tych zabiegów konstruowano spoiwo nowego rodzaju - wspólnota pewników miała zostać przekształcona we wspólnotę wahań i wątpliwości; wspólnota dumy we wspólnotę wstydu. Demitologizację i krytykę narodowej tradycji i narodowej pamięci robiono namiętnie i dobrze, do tego stopnia, że niewiele już zostało z dawnego modelu zbiorowej tożsamości Polaków ${ }^{41}$.

„Martyrologiczny upiór przystrojony w nieco odnowiony kostium postkolonialny to zaiste widok niezbyt zachęcający42", powiada Aleksander Fiut. Ów "upiór" dla sporej części twórców historii alternatywnych jest jednak nieodparcie nęcący, bo pozwala ewokować wyparte potrzeby. „Fantazmatyczność potrzeb” napotyka podatny materiał fantastycznej wizji, zdolnej powracać do wspaniałej przeszłości, a klęski przekuwać w sukcesy. Przypomnę, że Ernest Renan w szkicu Co to jest naród?43 zauważył, że dla kreowania tożsamości narodu tak samo istotne jak pamiętanie o zwycięstwach jest zapominanie o klęskach. Tym łatwiej zapominać o klęskach w obrębie historii alternatywnych. Czy jednak literackie, fikcyjne przekucie klęski w wygraną i np. uczynienie Polski zwycięzcą II wojny światowej jest zapomnieniem, czy może raczej swego rodzaju kontaminacją anagnorisis i anamnezy?

Wyparty, niewygodny fakt $\mathrm{z}$ historii realnej $\mathrm{w}$ historiach alternatywnych funkcjonuje w swej postaci zaprzeczonej, jest bezustannie towarzyszącym lekturze rewersem tego, o czym się czyta. Im wspanialsza alternatywna wizja przeszłości, tym bardziej przykre musi być przebudzenie i powrót do „skrzeczącej” rzeczywistości. Homi Bhabha, komentując esej Ernesta Renana, pisze, że „Zobowiązanie do zapomnienia staja się podstawą zapamiętywania narodu, zaludnienia go od nowa,

${ }^{40}$ T. Merta, Pamięć i nadzieja. W: Pamięć i odpowiedzialność. Red. R. Kostro i T. Merta. KrakówWrocław, s. 80-81.

${ }^{41} \mathrm{D}$. Gawin, O pożytkach i szkodliwości historycznego rewizjonizmu. W: Pamięć i odpowiedzialność..., s. 28.

42 A. Fiut, Polonizacja, kolonizacja. "Teksty Drugie” 2003, nr 6, s. 152.

${ }^{43}$ E. Renan, Co to jest naród. Przeł. S. Jedynak. W: Być w narodzie. Szkice o idei narodu, narodowej kulturze i nacjonalizmie. Red. L. Zdybel. Lublin 1998, s. 201. 
wyobrażenia sobie możliwości istnienia innych, alternatywnych i wyzwalających form identyfikacji kulturowej" 44 , tudzież „mnożenie się >alternatywnych historii wykluczonych $<" 45$. Wybrane przeze mnie historie alternatywne, stanowiące materiał badawczy tego szkicu, są właśnie formą wyobrażenia sobie owych alternatywnych form identyfikacji kulturowej - identyfikacji poprzez coś, czego nie było.

Alternatywno-historyczna twórczość Marcina Wolskiego (Alterland46; Wallenrod ${ }^{47}$; Jedna przegrana bitwa48; Mocarstwo ${ }^{49}$ ), Macieja Parowskiego (Burza. Ucieczka $z$ Warszawy '4050), Dariusza Spychalskiego (Krzyżacki poker ${ }^{51}$ ) opowiadanie Bomba Heisenberga Andrzeja Ziemiańskiego ${ }^{52}$, a także przynależący do nieliterackich, dziennikarskich i pop-historycznych historii alternatywnych Pakt Ribbentrop-Beck, czyli jak Polacy mogli u boku III Rzeszy pokonać Zwiazek Sowiecki Piotra Zychowicza ${ }^{53}$ uznać należy za realizację koniecznych fikcji (necessary fictions) opisanych przez Edwarda Saida i spopularyzowanych przez Homiego Bhabhę ${ }^{54}$. Termin ten oznacza tendencję narodów skolonizowanych/uzależnionych do kreowania mitologii własnej wspaniałej przeszłości, co ma spełniać funkcję narodowej autoterapii. Zarówno $\mathrm{H}$. Bhabha jak i E. Thompson zastanawiają się, na ile te fikcje, tudzież wymysły (tak termin przekłada E. Thompson), są naprawdę konieczne i czy naprawdę są one lekarstwem. Przypomnę, że greckie pharmakon oznacza zarówno lek, jak i truciznę, a każdy farmaceuta powie, że ostateczny efekt terapii zależy od proporcji i częstotliwości dawkowania leku.

Bhabha konstatuje, że takie „konieczne fikcje tragicznie zbyt mocno wierzą we własną koniczność, a zbyt słabo zdają sobie sprawę z własnej fikcyjności"55. Termin „konieczne fikcje” wydaje się zresztą szczególnie trafny w odniesieniu do historii alternatywnych. Bhabha, odwołując się do pierwotnego użycia terminu

${ }^{44}$ H. Bhabha, DysemiNacja. W: Miejsca kultury, op. cit., s. 170.

${ }^{45}$ Idem, Wstęp. W: Miejsca kultury, op. cit., s. XL.

${ }^{46}$ Warszawa 2003.

47 Warszawa 2009.

${ }^{48}$ Warszawa 2010.

${ }^{49}$ Warszawa 2012.

50 Warszawa 2009.

51 T. 1-2, Lublin 2009.

52 W tomie opowiadań Zapach szkła, Lublin 2004, pierwodruk w „Nowej Fantastyce” 2000, nr 9, s. $45-56$.

53 Poznań 2012.

${ }^{54}$ Na tekst E. Saida, Begginings, Baltimore\&London: John Hopkins University Press 1978, s. 76-77 powołuje się $\mathrm{H}$. Bhabha $\mathrm{w}$ tekście Representation and the Colonial Text: A Critical Exploration of Some Forms of Mimeticism. W: The Theory of Reading. Ed. by F. Gloversmith, Sussex \& New Jersey 1984, s. 93-122. Na gruncie polskim promotorami terminu są Ewa Thompson, Said i sarmatyzm, op. cit., oraz D. Skórczewski, Trudności z tożsamością. Na marginesie "Niesamowitej Stowiańszczyzny”. „Porównania” 2008, nr 5, s. 127-142; idem, Teoria - Literatura - Dyskurs, op. cit.

${ }^{55} \mathrm{H}$. Bhabha, Representation and the Colonial Text, op. cit., s. 97. Przeł. N. L. 
przez E. Saida, wskazuje na związek tychże z kategorią początku, historycznego momentu założycielskiego. Podporządkowani bowiem wynajdują/kreują mitologię swej przeszłości i początków sprzed momentu uzależnienia. Owo kreowanie początku $\mathrm{w}$ historiach alternatywnych koresponduje $\mathrm{z}$ niezbywalnym dla tego gatunku momentem zróżnicowania wydarzeń alternatywno-historycznych wobec tych znanych ze świata aktualnego. Moment ten bywa różnie nazywany: POD, point of divergance, nexus point, crucial point, zwrotnice czasu- zawsze jednak oznacza moment założycielski dla stworzonej wizji historii, np. wygrana II wojna światowa, wygrana bitwa, późniejsza śmierć danej postaci historycznej ${ }^{56}$. Literacka historia alternatywna stanowi rozwinięcie wybranego POD, nakreślenie jego konsekwencji. Początek jest, jak wiadomo, miejscem semantycznie szczególnie nacechowanym ${ }^{57}$, nic więc dziwnego, że odgrywa kluczową rolę również w kreowaniu alternatywnych koniecznych fikcji minionej, tudzież urojonej wielkości. Kreowanie hegemonicznej przeszłości w obrębie historii alternatywnych przynależy do pedagogiki narodowej (Bhabha) i jest ważnym elementem na mapie mentalnej narodu polskiego, jego mythomoteur, "zespołu mityczno-symbolicznego"58 (A. D. Smith), wreszcie - procesualności tożsamości narodu. Do pedagogiki akademickiej (Bhabha) odpowiadającej za "bezinteresowny model poznania ${ }^{59 "}$ przynależy rozpoznanie "falsyfikowalnych hipotez i narzędzi badawczych”. Pedagogika akademicka ma zatem m.in. uświadamiać, jak w obrębie historii alternatywnych realizowane są postulaty pedagogiki narodowej (D. Skórczewski) ${ }^{60}$. Postkolonialne potrzeby narodu artykułują potrzebę fikcji hegemonicznych, efektu postkolonialnej traumy i poczucia skrzywdzenia przez historię, pedagogika uniwersytecka ma za zadanie przypomnieć jednak, że zdaniem Leszka Koczanowicza ${ }^{61}$ i Macieja Janowskiego ${ }^{62}$ Polsce nie przypadło w historii jakieś szczególnie wybitne zadanie. Koczanowicz w tym miejscu przypomina, że zasadniczym przesłaniem teorii postkolonialnej jest wyzwolenie od mitów: zarówno tych narzuconych przez kolonizatora, jak i własnych, pielęgnowanych przez subalterna jako antidotum na sytuację podrzędności. Zastosowanie, choć $\mathrm{w}$ nieco inny sposób, ma tu słynna formuła Ngũgĩ wa Thiong'o - „dekolonizacja to proces dekolonizacji umysłów” 63.

56 Por. A. Demandt, Historia niebyta. CO by byto, gdyby...? Przeł. M. Skalska. Warszawa 1999.

$57 \mathrm{~J}$. Łotman, O modelującym znaczeniu "końca" $i$ "poczatku” $w$ przekazach artystycznych. W: Semiotyka kultury. Wybór i oprac. E. Janus i M. R. Mayenowa. Warszawa 1977, s. 344-349.

${ }^{58}$ A. D. Smith, Etniczne źródta narodów, op. cit., s. 20.

59 Ibidem, s. 101.

60 D. Skórczewski, Drogi i rozdroża studiów postkolonialnych w Polsce. W: Teoria - Literatura Dyskurs, op. cit., s. 101 i n.

${ }^{61}$ L. Koczanowicz, Post-komunizm a kulturowe wojny. W: Kultura po przejściach. Osoby z przeszłościa, op. cit., s. 26.

62 M. Janowski, Polityka historyczna: między edukacją historyczna a propagandą. W: Pamięć i polityka historyczna. Doświadczenia Polski i jej sąsiadów. Red. S. Nowinowski, R. Stobiecki. Łódź 2008, s. 234.

${ }^{63}$ Ngũgĩ wa Thiong'o, Decolonising the Mind. The Politics of Language in African Literature. London 1986. 
Wybrane przeze mnie hegemoniczne historie alternatywne Polski to pole oddziaływania obserwowanego przez Hannę Gosk procesu „redefini[cji] statusu ofiary, przekształc[enia] niepostrzeżenie $\mathrm{w}$ hegemona dominującej opowieści, kogoś narzucającego ton, dyskutującego skalę wartości, decydującego o tym, co godne, honorowe" 64 . Słowem, działa tutaj opisany przez Chelę Sandoval uprzywilejowany poznawczo status ofiary (,epistemic privilge of the oppressed") 65 , w którym o własnych krzywdach pamięta się obsesyjnie, zaś swoich złych uczynków wobec innych się nie wspomina. Maria Janion pisała o tym, że Polska charakteryzuje się paradoksalną mentalnością postkolonialną, przejawiającą się w poczuciu bezsilności, ale i „mesjanistycznej dumy wyrażonej poprzez narracje o wyjątkowości polskiej ofiary i cierpień zadanych przez niesprawiedliwą historię" 66.

Interesujących informacji dostarcza krótkie porównanie polskich i zachodnich historii alternatywnych. Catherine Gallagher wskazuje zachodnie historie alternatywne powstające $w$ latach siedemdziesiątych i osiemdziesiątych XX wieku jako literacki moment etycznego działania logiki sprawiedliwości historycznej oraz procesu odszkodowawczego ${ }^{67}$. W amerykańskich historiach alternatywnych pojawiają się scenariusze budujące kreujące np. sprawiedliwszy kurs wobec Indian ${ }^{68}$, czy wobec czarnej ludności po okresie wojny secesyjnej. Owo historyczno-alternatywne posypywanie głowy popiołem jest jednak, jak mi się wydaje, spowodowane faktem, iż USA były i są hegemonem, zatem kreowanie takich scenariuszy nie stanowi zagrożenia dla pozycji państwa, a nawet może ją umocnić o etyczny element ekspiacji. W polskich historiach alternatywnych zaś trudno by szukać jakichkolwiek form zadośćuczynienia wobec Litwy, Ukrainy, Białorusi. Państwa te wciąż, co poniżej wykażę, są opisywane w historiach alternatywnych jako szczęśliwe z powodu polskiej opieki i preponderancji kulturowej. Polska jest wobec „młodszych" narodów Europy, starszym, mądrzejszym bratem (pisarstwo Marcina Wolskiego, czy Pakt Ribbentrop-Beck Zychowicza, Bomba Heisenberga Ziemiańskiego). Pobrzmiewają tu echa widzianego w kolonialnym aspekcie projektu Oświecenia, jako wyjścia z wieku niedojrzałości, a skolonizowanego - jako dziecka ${ }^{69}$.

${ }^{64}$ H. Gosk, Opowieść „skolonizowanego/ kolonizatora”, op. cit., s. 19.

${ }^{65}$ Ch. Sandoval, Methodology of the Opressed. London 2000; E. Domańska, Historie niekonwencjonalne. Refleksja o przeszłości w nowej humanistyce. Poznań 2006, s. 18 i nast.; E. Domańska, O poznawczym uprzywilejowaniu ofiary (Uwagi metodologiczne). W: (Nie)obecność. Pominięcia i przemilczenia w narracjach XX wieku. Red. H. Gosk, B. Karwowska. Warszawa 2008, s. 19-36; E. Domańska, Historiografia insurekcyjna. „Literatura na Świecie” 2008, nr 1/2, s. 355-368; b. hooks, Margines jako miejsce radykalnego otwarcia. Przeł. E. Domańska. „Literatura na Świecie” 2008, nr 1-2, s. 108-118.

${ }^{66}$ M. Janion, Niesamowita Stowiańszczyzna: fantazmaty literatury. Kraków 2006, s. 11.

${ }^{67}$ C. Gallagher, Dlaczego opowiadamy jak nie byto?, op. cit., s. 145.

68 Przykładowo, w cyklu Orsona Scotta Carda o Alvinie Stwórcy (Siódmy syn i nast.) na terenach Ameryki Północnej znajduje się niezależne, liczące się politycznie państwo indiańskie.

${ }^{69}$ L. Gandhi, Teoria postkolonialna. Wprowadzenie krytyczne. Przeł. J. Serwański. Poznań 2008, s. 35 i n. 
W amerykańskim projekcie pisania narodu moment ekspiacji jest oczywisty, bo, jak już pisałam, stoi za nim niezbywalna pozycja hegemona, a na polskim „pisaniu narodu" ciąży pozycja ofiary, nieskłonna do wypuszczenia z rąk choćby i fikcyjnej wielkości.

Interesujące, że w Polsce przez II wojną światową powstawały utwory, które można uznać za zjawiska gatunkowo podobne, bądź inwarianty historii alternatywnych. Są to tzw. historie przyszłości, rzutujące w przyszłość wizję Polski posiadającej rozliczne kolonie np. (Edward Krüger, Ludzie elektryczni, czy Kazimierz Andrzej Czyżowski, Maciek I, król powietrza) czy też stającej się paneuropejskim mocarstwem (Włodzimierz Zagórski W XX wieku, czy Czandu Stefana Barczewskiego $)^{70}$. Fakt, iż chętniej pisywano o przyszłości, jest znaczący i to podwójnie. Po pierwsze, pisarze chcieli wreszcie wiosną „wiosnę a nie Polskę zobaczyć", ale wierzyli w to, że, odzyskawszy niepodległość, Polska ma realną szansę zdobyć się na prawdziwą wielkość. Wymienione powieści spełniały więc rolę "samospełniającej się przepowiedni", stanowiąc również ważny element "pisania narodu” i narodowej pedagogiki, dowodząc tym samym optymizmu politycznego. Wydaje się więc, że po 1989 roku dominacja gatunku historii alternatywnej, kreującej hegemoniczne wizje Polski jedynie $\mathrm{w}$ odniesieniu do przeszłości, jest efektem utraty naiwnej wiary okresu świeżo po restytucji polskiej państwowości w 1918 i przejścia narodu przez okres II wojny światowej i komunizmu, które ostatecznie pogrzebały wiarę $\mathrm{w}$ realną wielkość. Nie jest więc dziełem przypadku, że historie alternatywne niezwykle intensywnie rozwijają się w Polsce po $1989 \mathrm{r}$. Zniesienie cenzury umożliwiło mówienie o zatajonych wcześniej, niewygodnych dla rządzących epizodach naszej historii, bądź prze-pisanie, odmienne zinterpretowanie i ocenienie w sposób subwersywny tych obecnych w podręcznikach historii. Również w środowisku zawodowych historyków zaczęły pojawiać się głosy wzywające do odbrązowienia, bądź przeciwnie - dowartościowania niektórych postaci czy całych okresów historycznych. Historia alternatywna stała się po 1989 roku swego rodzaju przedłużeniem subwersywnego nurtu fantastyki socjologicznej $\mathrm{z}$ lat 70-tych i 80-tych, który był, jak wiadomo, czynioną językiem ezopowym, krytyką sytuacji w komunistycznej Polsce ${ }^{71}$.

${ }^{70}$ Wszystkie wymienione powieści przypomnieli Agnieszka Haska i Jerzy Stachowicz w pracy Śniąc o potędze. Warszawa 2012. Książka ta stanowi antologię przedwojennych historii alternatywnych, choć muszę zaznaczyć, iż większość wybranych przez autorów tekstów to właśnie historie przyszłości, co stanowi istotną różnicę.

${ }^{71}$ Por. A. Mazurkiewicz, Między fantastyka a iluzją. Social Fiction jako kryptopolityczny nurt polskiej literatury lat siedemdziesiatych $i$ osiemdziesiatych XX w. "Acta Universitatis Lodziensis" Folia Litteraria Polonica 2011, nr 14, z. 2, s. 178-191; M. Leś, Fantastyka socjologiczna. Poetyka i myślenie utopijne. Białystok 2008; R. Klementowski, Modelowe boksowanie ze światem. Polska literatura fantastyczna na przełomie lat 70. i 80. Toruń 2003; M. Parowski, Kilkunastu Hamletów. W: Czas fantastyki. Szczecin 1990, s. 293-319; J. Szacki, Spotkania z utopia. Warszawa 1980, 2000; Na wirażu. Dyskusja redakcyjna z udziatem Edmunda 
Prezentację hegemonicznych alternatywnych wizji przeszłości i teraźniejszości Polski zacznę od opowiadania Andrzeja Ziemiańskiego pt. Bomba Heisenberga. W wykreowanym na potrzeby tego utworu świecie Polska jest królestwem, Rzeczpospolitą Trojga Narodów, składającą się z narodów: polskiego, litewskiego. Trzecim narodem nie są jednak Ukraińcy, a Żydzi. Kraj rządzony jest przez króla Henryka XI Jagiellończyka i znajduje się w ścisłym sojuszu z Państwami Osi: III Rzeszą, Włochami i Japonią, do której przyłączają się Austro-Węgry i frankistowska Hiszpania. Opowiadanie rozgrywa się w alternatywnym odpowiedniku lat sześćdziesiątych XX w., kiedy córka Adolfa Hitlera i Ewy Braun jest już osobą dorosłą. Za taką datacją przemawia również to, że polskie wojsko bierze udział $\mathrm{w}$ wojnie wietnamskiej. Za niewskazany literalnie moment POD należy przyjąć niewygaśnięcie dynastii Jagiellonów, o czym świadczy fakt, że Henryk XI zwany jest bezpośrednim potomkiem zwycięzców spod Grunwaldu. Wrogiem Polski jest oczywiście Związek Sowiecki. Nie wiedzieć czemu, w ramach dywersji, żołnierzom Rzeczpospolitej Trojga Narodów puszczane są piosenki Hanki Ordonówny. Co ciekawe, Polskę w świecie Ziemiańskiego cechuje pragmatyzm polityczny, bo jako jedyne państwo Osi nie wypowiedziała ona wojny USA, przedkładając korzyści gospodarcze płynące $z$ handlu nad „idiotyczne machanie szabelką72”. Ponieważ Polska ma sprzymierzyć się bliżej z Niemcami, główny bohater opowiadania, nomen omen generał Jaremi Wiśniowiecki, powinien poślubić Monikę Hitler. Wytłumaczenie tej konieczności wiele powie o postkolonialnych fantazmatach i resentymentach: „Jak już mówiłem, Rzeczpospolita zamierza teraz postawić na Niemcy. W tym celu, Monisia musi być, wybacz wulgaryzm, dupczona przez naszego człowieka ${ }^{73 "}$. W ten oto sposób realizuje się odwrócony, terapeutyczny scenariusz „kolonialnego pożądania” opisywany przez Roberta Younga74, według którego podbijanie kolejnych kolonii traktowane było jako gwałt, czemu sprzyja nawet semantyka „kolonialnej penetracji”. Ewa Thompson pisze natomiast, że „Kolonializm jest zwykle następnym stadium nacjonalizmu agresywnego, zaś jego zakorzenienie $\mathrm{w}$ tradycyjnej hegemonii męskiej jest zbyt oczywiste, by wymagało argumentów"75. Hanna Gosk wpisuje się w te rozważania, zadając pytanie, dlaczego literackie opisy związków Polek z Rosjanami prowokowały oskarżenia o zdradę narodu, zaś w sytuacji odmiennej relacji już nie ${ }^{76}$. Sprawa stosunków seksualnych Polaka z upodrzędnionymi Rosjankami pojawia się też w twórczości Marcina

Wnuka-Lipińskiego, Marka Oramusa, Marcina Wolskiego, Jacka Inglota, Doroty Malinowskiej, Adama Hollanka, Lecha Jęczymyka i Macieja Parowskiego. „Nowa Fantastyka” 1990, nr 10, s. 62-67.

72 A. Ziemiański, Bomba Heisenberga. „Nowa Fantastyka” 2000, nr 9, s. 45.

73 Ibidem, s. 51.

${ }^{74}$ R. Young, Colonial Desire: Hybridity in Theory, Culture and Race. London 1995.

75 E. Thompson, Trubadurzy Imperium. Literatura rosyjska i kolonializm. Przeł. A. Sieroszulska. Kraków 2000, s. 11.

${ }^{76}$ H. Gosk, Opowieść „kolonizatora/skolonizowanego", op. cit., s. 24. 
Wolskiego (Mocarstwo), o czym piszę poniżej. Wydaje się, że stosunek Polaka biorącego w posiadanie w Niemkę bądź Rosjankę jest swego rodzaju projektem odzyskiwania przeszłości i godności. Seksualność i kolonialność mają wspólny mianownik. To czynnik męski jest zdobywcą, zaś żeński jest zdobywany/podbijany. Kiedy więc gen. Wiśniowiecki w Bombie Heisenberga ma "dupczyć” Monikę Hitler - w imię interesu ojczyzny, bo dzięki temu miałby w przyszłości zostać królem Polski, a skoro w jego żyłach płynie również krew Hohenzollernów - to być może i Rzeszy Niemieckiej, dzięki czemu powstałaby Rzeczpospolita Czworga Narodów, realizująca alternatywną wersję Ottona III - do głosu dochodzi silna gra resentymentów.

Również Dariusz Spychalski w Krzyżackim pokerze postanowił dać wyraz trwałości mitu jagiellońskiego. W jego powieści Rzeczpospolita Trojga Narodów w alternatywnych latach pięćdziesiątych XX w. rozciąga się od morza do morza, a nawet posiada kolonie w Afryce. Zakon Krzyżacki wciąż corocznie składa Polsce hołd lenny, starając się jednak wszelkimi dostępnymi sposobami uniezależnić od Rzeczpospolitej. Spychalski kontaminuje tym samym dwa okresy i mity polskiego kolonializmu: mit jagiellońskiego złotego wieku z następującymi po odzyskaniu niepodległości, choć zakorzenionymi już u schyłku XIX wieku, marzeniami i dążeniami Polski o dołączeniu do potęg kolonialnych. Wierzono wtedy, że kolonie w Afryce należą się Polsce jako moralne odszkodowanie za lata zaborów. Najpełniejszym wyrazem tych kolonialnych tęsknot była działalność Ligi Morskiej i Kolonialnej powstałej w roku 1930. W powieści Spychalskiego Polska znów/nadal jest antemurale christianitatis, bo kalifaty arabskie zagrażają chrześcijańskiej Europie. Znaczące, choć zgodne z podzielaną przez autora ideą Rzeczpospolitej Trojga Narodów, jest że Spychalski nie poświęca wiele uwagi losom stowarzyszonych z Polską krajów Liwy i Ukrainy. Milcząco przyjmuje, że państwa te są zadowolone z opieki politycznej i kulturalnej Polski. Spychalski w Krzyżackim pokerze realizuje w zasadzie wszystkie najważniejsze "ambicje” imperialne Polski, skierowane zarówno na Zachód - Zakon Krzyżacki jako odwieczny lennik - oraz na Wschód mit kresowy w jego najszerszym wydaniu.

Kto wie, czy nie potężniejszy obraz Polski wspaniałej i tryumfującej przynosi Burza. Ucieczka z Warszawa '40 Macieja Parowskiego77 - Polski zbyt pięknej, by mogła być prawdziwą - wybaczającej, tryumfującej i wielkiej duchem ${ }^{78}$. Parowski $\mathrm{w}$ wypowiedziach okołoliterackich nie buduje jednak radykalnego programu politycznego, więc i odbiór jego powieści jest inny - spokojniejszy, bez wysokiej temperatury politycznej. Niemcy zostają zatrzymane na skutek apokaliptycznej ulewy, która spada na Polskę we wrześniu 1939 roku. Ciężki sprzęt wojskowy III Rzeszy grzęźnie w błocie, za to polska kawaleria radzi sobie znakomicie. Polska

77 M. Parowski, Burza. Ucieczka z Warszawy ‘40. Warszawa 2009.

${ }^{78}$ Por. W. Gruszczyński, Cud wyśniony..., op. cit. 
jest wyzwolicielem Europy, Hitler został zesłany na wyspę świętej Heleny, a Warszawa to stolica kulturalna Europy. Nawet Leni Riefenstahl mówi, że „dziś wszyscy przyzwoici ludzie są polskimi patriotami". Burza Parowskiego to jednak utwór wielowymiarowy: buduje obraz wielkiej Polski i równocześnie poddaje go w wątpliwość. Na trop podejrzliwej względem trybu historii „ku pokrzepieniu serc" naprowadza chociażby obraz „polskich obozów koncentracyjnych, w których trzymamy szczególnie wrednych Niemców ${ }^{79 "}$.

Jednym z najbardziej rozpoznawalnych autorów historii alternatywnych jest w Polsce niewątpliwie Marcin Wolski. Pisarz słynie z prawicowych, zdecydowanie antykomunistycznych poglądów politycznych. Regularnie publikuje w "Gazecie Polskiej” i sympatyzuje z PiS. Wolski jest przekonany o konieczności krzewienia patriotyzmu i pielęgnowania narracji o wspaniałych, tryumfalnych momentach polskiej historii:

Lubię opowieści, które się dobrze kończą, zwłaszcza że prawdziwa historia, szczególnie Polski, obfituje w wątki kończące się źle. Do tego stopnia, że autorzy piszący dla pokrzepienia serc musieli urywać swe opowieści w najciekawszym momencie; Sienkiewicz, jak wiadomo, zamknął Trylogię zwycięstwem pod Wiedniem, choć synom Skrzetuskiego i Kmicica przyszło zapewne żyć w czasach saskiej niemocy ${ }^{80}$.

Pisarz, by nie urywać swych opowieści w najciekawszym momencie, zmienia więc "złą" przeszłość. Na przykład w opowiadaniu Lustro i kolumna ${ }^{81}$ w efekcie wiktorii pod Kłuszynem (1610 r.) Władysław IV zostaje wybrany na cara Wszechrusi. Gdyby ów alternatywny scenariusz ziścił się również w rzeczywistości, zdaniem pisarza: „z pewnością rocznica »wypędzenia Polaków w Moskwy« nie byłaby dziś świętem w putinowskiej Rosji" ${ }^{2}$. Marcin Wolski w trzech powieściach (Alterland, Wallenrod, Mocarstwo) powiela ten sam scenariusz historyczny, w którym sprzymierzona z Hitlerem Polska ${ }^{83}$ roznosi w proch Imperium Sowieckie, a następnie wykonuje genialną woltę i w samą porę sprzymierza się $\mathrm{z}$ aliantami, w gronie których nie ma, oczywiście, upokorzonych, słabych Sowietów. Powracanie do tego scenariusza jest u Wolskiego obsesją i nosi znamiona pisarstwa histerycznego ${ }^{84}$. Posługujący się nim historycy oraz pisarze

${ }^{79}$ M. Parowski, Burza, Ucieczka z Warszawy'40, op. cit., s. 53.

${ }^{80} \mathrm{M}$. Wolski, O pożytku z historii alternatywnych. W: W poszukiwaniu pożyteczności gatunku historii alternatywnych..., op. cit., s 17.

${ }^{81}$ Idem, Lustro i kolumna. W: Wizje alternatywne 4. Red. W. Sedeńki. Warszawa 2002, s. 9-62.

${ }^{82}$ Idem, O pożytku..., s. 19.

${ }^{83} \mathrm{~W}$ tym miejscu przypomnę jedynie, że A. Fiut w eseju Polonizacja? Kolonizacja? pisał „serce niejednego "prawdziwego« Polaka wzdrygnie się z pewnością na miano kolonizatora i to jeszcze u boku Niemców”. „Teksty Drugie” 2003, nr 6, s. 154.

${ }^{84} \mathrm{~A}$. Mach, Polska kondycja posttraumatyczna - próba diagnozy. W: Kultura po przejściach, osoby z przeszłościa, op. cit., s. 220-221. 
Traktują traumę jako użyteczny trop, a czasem konwencję mówienia o »sobie i świecie«, wyrażającą nierzadko pragnienie skonstruowania sobie traumatycznej przeszłości według wzoru ławo poddającego się »histerycznej« interpretacji niż rzeczywista trauma ${ }^{85}$.

Moim zdaniem, tę diagnozę można idealnie zastosować do trybu pisania Marcina Wolskiego, skoro w każdej z wymienionych powieści protagonista jest czytelnym porte-parole autora, który każdorazowo w nieco innym wcieleniu ponownie „przeżywa” traumę komunizmu. W Alterlandzie mowa jest wprost o wysiłkach prowadzących do tego, by zwyciężyło dobro i, tym samym, dobra historia: „»Chronos« [wehikuł czasu: N.L] miał doprowadzić do tryumfu dobrej historii nad złą8". Za wyborami alternatywnych scenariuszy stoi przekonanie, iż ZSRR był dużo gorszym i bardziej szkodliwym agresorem niż III Rzesza. Powodem takiej oceny są, oczywiście, dzieje PRL, pozwalające na demonizowanie Rosjan i bagatelizowanie niemieckiego zagrożenia. Wolski zdaje się mówić, że Niemcy dławili naród polski „jedynie” lat 6, zaś komuniści - pięćdziesiąt. W wymienionych powieściach Wolski składa hołd historykowi Pawłowi Wieczorkiewiczowi, który promował scenariusz Polski u boku III Rzeszy ${ }^{87}$. W Wallenrodzie Piłsudski żyje 5 lat dłużej, uleczony z raka przez tajemniczego doktora - Wolski sugeruje, że terapia była dziełem ojca Pio, dzięki czemu uzdrowienie Marszałka wpisuje się w romantyczny, prowidencjonalistyczny mit Polski jako zbawcy narodów - i wchodzi w sojusz z Hitlerem. Polska i Niemcy wspólnie atakują Rosję, a Zachód jest miażdżony przez Rzeszę Niemiecką. Udaje się zabić Stalina, a Piłsudski odradza Hitlerowi Holocaust. Kiedy jednak Piłsudski doznaje wylewu, Hitler wraca do planu eksterminacji Żydów, chcąc zrzucić bombę atomową na powstałą na Ukrainie Nową Jerozolimę. Uniemożliwia to jednak agentka polskiego wywiadu, tytułowy Wallenrod. Ciekawe jednak, że w późniejszym Mocarstwie bomba spada na Nową Jerozolimę, stolicę państwa żydowskiego i dokonuje się atomowy Holocuast. W Wallenrodzie tak się jednak nie dzieje. Hitler ginie, a Polska staje się największą potęgą europejską. Wobec takiego scenariusza od razu spolaryzowały się stanowiska. Na łamach „Polityki” Adam Krzemiński pisał: „Oto naiwna i niebezpieczna tęsknota zrodzona z kompleksów" 88 , zaś Bohdan Urbankowski, reprezentujący zgoła odmienną opcje polityczną, uznał na łamach „Gazety Polskiej” Wallenroda za najlepszą powieść, jaką napisał Wolski, przyznając jednak, że

${ }^{85}$ Ibidem, s. 221.

${ }^{86}$ M. Wolski, Alterland, op. cit., s. 89

${ }^{87}$ Napiszmy historię od nowa. Rozmowa Pawła Wieczorkiewicza z Piotrem Zychowiczem, „Rzeczpospolita" 2009, 27.03.; P. Wieczorkiewicz, Wrzesień 1939 - próba nowego spojrzenia, "Mówią Wieki”. 2009, nr 9, s. 24-30; Tenże, Bilans kampanii. W: Kampania 1939 roku. Warszawa 2001.

88 A. Krzemiński, Bajania w hitlerianach, „Polityka”, nr z dn.5.4.2010, http:/ / www.polityka.pl/ kultura/1504440,1,hitler-historie-alternatywne.read?print=true\#ixzz1cj9yg9Sf (data dostępu: 4.11.2011). 
opowiadanie alternatywnej historii - a tym jest między innymi Wallenrod - to coś więcej niż kłamstwo, a czasem - coś więcej niż prawda. Autor zaprasza nas do wspólnoty wtajemniczonych $\mathrm{w}$ mechanizmy dziejów, wyzwala $\mathrm{w}$ nas smakoszy chwytających w lot każdą aluzję - czym zręcznie łaskocze naszą próżność. Podejrzewam, że robi to także pod wpływem własnej próżności. Podejrzewam, że pisząc miał poczucie, iż udaje mu się poprawić dzieło Ducha Dziejów ${ }^{89}$.

Pisarskie wybory Wolskiego potwierdzają to, o czym pisał Koczanowicz ${ }^{90}$, sugerując, że w dobie postkomunistycznych wojen kulturowych miarą polskości staje się uznanie, iż rozwój naszego kraju po 1945 roku miał bezdyskusyjnie charakter zależnościowy. Sam Marcin Wolski na łamach „Gazety Polskiej” potwierdzał zaobserwowany przez Koczanowicza podział na „Polskę Prawdziwą”, patriotyczną, Polskę AK i Solidarności, oraz na „Polskę nieprawdziwą”, liberalną:

Oglądajmy bieżące sztuki i spektakle kabaretowe, wybierzmy się na Seks polski niejakiego Rafała Rutkowskiego, na którym publika rży z katastrofy smoleńskiej. (W normalnym kraju ktoś taki miałby trudności z dalszym uprawianiem zawodu). Odnotujmy to, co się nagradza, nagłaśnia, wysyła w świat z błogosławieństwem "Nike" i paszportem „Polityki” (...) Ludźmi o zaniżonej samoocenie o wiele łatwiej rządzić, są lepszym materiałem do manipulacji bądź do prowokacji. A w dalszej przyszłości do wykorzenienia i wynarodowienia. [...] A my? Nie daliśmy się skacapić ani za cara, ani za bolszewika, między innymi dlatego, że odczuwaliśmy wyższość narodu ludzi wolnych nad czynownikami i rabami z „więzienia narodów”. I dlatego, mimo miażdżącej krytyki, uważam, że należy pisać „ku pokrzepieniu serc”, ku wzmacnianiu dumy z bycia Polakiem i satysfakcji z dokonań w przeszłości, bo to pozwala wierzyć w przyszłość i porywać się na zadania wielkie i ambitne. Z pełną świadomością piszę w moich historiach o dynastii polskich Wazów na Kremlu (Wilk w owczarni), o zwycięstwie Polski w II wojnie światowej i nad Wschodem, i nad Zachodem (Wallenrod) czy o ratunku, jakim dla podbitego ludu przebywającego w diasporze mógł być jeden święty człowiek używający pseudonimu Jan Pawłowicz (Jedna przegrana bitwa). Aby odnosić sukcesy w jakiejkolwiek dziedzinie, trzeba najpierw uwierzyć w siebie! ${ }^{91}$

Wypowiedź ta potwierdza tezę Ewy Thompson, iż trauma postkolonialna nie została w Polsce przepracowana, a wszelkie resentymenty i przekonanie o minionej wielkości są dowodem mimikry postkolonialnej . Zarówno w Wallenrodzie, jak i w Mocarstwie pojawia się paraboliczny wątek smoleński, co dowodzi prawdziwości tezy, że historie alternatywne mówią tyle samo, jeśli nie więcej, o współczesności niż o przeszłości. W Wallenrodzie Józef Piłsudski miał na skutek zamachu zginąć

${ }^{89}$ B. Urbankowski, Piękna pani Wallenrod, "Gazeta Polska” cyt. za: http://www.zwrotniceczasu. nck.pl/seria_ksiazkowa.html?rec=11 (data dostępu: 4.11.2011).

90 L. Koczanowicz, Post-komunizm a wojny kulturowe. W: Kultura po przejściach. Osoby z przeszłościa, op. cit., s. 17.

${ }^{91}$ M. Wolski, Samoocena. http:/ / niezalezna.pl/10703-samoocena (data dostępu: 5.1.2012). 
z ręki sowieckiej w katastrofie samolotowej, zaś w Mocarstwie to samo miało spotkać prezydenta Polski Tadeusza Zawadzkiego, znanego w świecie aktualnym jako uczestnika akcji pod Arsenałem. W Mocarstwie zamach zostaje udaremniony, choć na pokładzie samolotu wybuchnąc miała bomba termobaryczna, która uzbraja się po zejściu na odpowiednio niski pułap...W Mocarstwie wprost wyeksplikowano alternatywne przekonanie o potędze Polski: „Wedle mej koncepcji Polska i tak stanie się mocarstwem Międzymorza. Historia w każdym wariancie skazała nas na wielkość92". W powieści tej działa zasada prostego wzięcia odwetu na przeszłości, zgodnie z mechanizmem o którym pisał Franz Fanon:, „Skolonizowany jest zawistny. Kolonizator o tym wie (...)»Oni chcą zająć nasze miejsce«93".

W Mocarstwie pojawia się wiele symbolicznych obrazów zemsty: tryumfujące wojska sprzymierzonych Polski i III Rzeszy defilują po Placu Czerwonym, a premier Sikorski przyjmuje zmianę warty na Kremlu ${ }^{94}$, zaś Stalin zostaje zamordowany $\mathrm{w}$ Swiedłowsku, w tym samym domu, w którym zamordowano rodzinę ostatniego cara ${ }^{95}$. Pisarz daje też wyraz swemu rozczarowaniu postawą niedotrzymującej umów Wielkiej Brytanii:

Dwa dni później rozpoczęło się bombardowanie Londynu... Z mieszanymi uczuciami - zażenowaniem pomieszanym z mściwą satysfakcją za wszystkie zdrady aliantów dokonane w moim świecie - czytałem o udziale polskiej eskadry łosi dowodzonej przez majora Skalskiego w nalotach na Londyn... ${ }^{96}$.

Przy okazji pojawiają się niebezpieczne nuty antysemickie. Pisarz powraca do scenariusza przesiedlenia przez Hitlera polskich Żydów na Białoruś i stworzenia tam państwa Izrael, ze stolicą w Nowej Jerozolimie. Tym samym daje wyraz kolonialnemu poczuciu wyższości, skoro $\mathrm{w}$ jego świecie Białoruś, jako kraj „nieistotny" , mogła stać się ojczyzną dla niepożądanych w cywilizowanej Europie Żydów. W Mocarstwie na Nową Jerozolimę spada jednak bomba atomowa, uderzając na Czernobyl, który, co trzeba zaznaczyć, w świecie rzeczywistym znajduje się na Ukrainie, a nie na Białorusi. Bomba atomowa zmiata naród żydowski z powierzchni ziemi, działając tym samym dużo skuteczniej niż hitlerowskie obozy zagłady znane ze świata aktualnego. W Mocarstwie padają również słowa: „Kiedy czytam w opowiadaniach młokosa nazwiskiem Zajdel o przemysłowej likwidacji europejskich Żydów za pomocą gazu w specjalnie budowanych komorach...".

Janusz Zajdel był, jak wiadomo, czołowym twórcą dystopijnej fantastyki socjologicznej, słowa te niebezpiecznie zbliżają się zatem do rewizjonizmu.

${ }^{92}$ M. Wolski, Mocarstwo, op. cit., s. 50.

${ }^{93}$ F. Fanon, Wyklęty lud ziemi. Przeł. H, Tygielska. Przedm. E. Rekłajtis. Posł. J.-P. Sartre. Warszawa 1985, s. 22.

${ }_{94}$ M. Wolski, Mocarstwo, op. cit., s. 62.

${ }^{95}$ Ibidem, s. 63.

${ }^{96}$ Ibidem, s. 66. 
Kolejnym elementem oddziaływania resentymentu, odwracającego $\mathrm{w}$ prostej mimikrze doznane urazy, jest opisywanie Rosji jako kraju, który na skutek działań Polaków jest słaby i podzielony na dwa niezbyt istotne politycznie państwa. W Mocarstwie Rosjanie, stojący niżej cywilizacyjnie niż Polacy, są służącymi. Rosjanka Natasza Kryłowa jest opiekunką dzieci w domu polskich nowych arystokratów, a główny bohater odczuwa w stosunku do niej silny popęd seksualny, zmierzający tyleż do jej zdobycia fizycznego, co zniewolenia, zgodnie z przywoływaną już zasadą kolonialnego pożądania (R. Young). We wcześniejszym Alterlandzie natomiast pojawia się wizja historii gorszej niż aktualna - Polska jest republiką sowiecką, bo powiódł się zamach na Hitlera i Stalin nie miał żadnych wrogów. W celu naprawienia chorej historii, tj. ratowania Hitlera, rusza misja alternautów - jako symbol zniewolenia i upodlenia Polski pojawia się znany z literatury rozbiorowej motyw Polek, jako idealnych kochanek dla Rosjan. Pogardy kolonizatora dla skolonizowanego dowodzi język uprzedmiatawiający subalterna: „próbował pan Polek, profesorze? Nikt nie kocha tak jak Polki ${ }^{97 "}$. W Mocarstwie $\mathrm{w}$ polskich domach do stołu podają Wietnamki, a gotują Murzynki. W świecie wykreowanym przez Wolskiego jest to efekt podjęcia przez Polaków „brzemienia białego człowieka”. W ten sposób Polacy „pomagają” wdowom po poległych w Wietnamie i Kongu. Polska posiada również afrykańskie kolonie, tj. Tanganikę, realizując tym samym marzenia Ligi Morskiej i Kolonialnej.

Również Jedna przegrana bitwa nosi znamiona pisarstwa histerycznego, wprost opartego na kodzie alternatywnej biografii. Tym razem jednak pisarz sięga po scenariusz dystopijny, "pozwalając wygrać złu 98 " - przegrana w Bitwie Warszawskiej w 1920 r. uczyniła z Polski kolejną republikę radziecką. Pisarz podaje następujące powody powstania Jednej przegranej bitwy:

A przy okazji spłacić dług swoim dziadkom, stryjom, ojcu - statystom wielkiej batalistyki. Czy to nie symboliczne, że z czterech braci Wolskich urodzonych na przełomie wieków jeden zginął, walcząc z bolszewikami nad Dźwiną, drugi w Oświęcimiu, trzeci zmarł wkrótce po wyjściu ze stalinowskiego więzienia, a czwarty, mój ojciec, zdołał być i pod Warszawą w 1920, i w Mauthausen w latach1944-1945, i zostać przez komunę pozbawionym prawa wykonywania zawodu adwokata. Ta historia żyła we mnie od zawsze, dzięki opowieściom Babci, mamy, gosposi, dzięki pamiętnikowi mojego ojca, który aż do 13 sierpnia 1920 roku przytaczam nieomal dosłownie. Wiedząc, jak historia mojej rodziny i naszego świata rozegrała się naprawdę, nie mogłem odmówić sobie podjęcia próby sprawdzenia, jak mogłaby potoczyć się inaczej ${ }^{99}$.

W tym kontekście pierwsze słowa powieści brzmią dojmująco: „Byłem niewolnikiem. Urodziłem się jako niewolnik. I wszystko wskazywało na to, że jako

\footnotetext{
${ }^{97}$ M. Wolski, Alterland, op. cit., s. 8.

${ }_{98}$ M. Wolski, Jedna przegrana bitwa, op. cit., 2

${ }^{99}$ Ibidem.
} 
niewolnik umrę100". Wolski rozwija więc scenariusz, w którym główny bohater, Marcin Wolak, jest nagradzanym poetą, pisującym hymny pochwalne ku czci Dzierżyńskiego. Wszystko jednak zmienia się, kiedy od nieznajomego człowieka dostaje rękopis pamiętnika dawnego żołnierza Piłsudskiego, który opisuje swe życie, począwszy od przegranej Bitwy Warszawskiej. Autorem dziennika i człowiekiem, który go dostarczył młodemu poecie, był jego ojciec, który przeszedł przez piekło Syberii a następnie uciekł na Zachód. Ojciec jest prawdziwym patriotą, który porzucił matkę Marcina dla walki z Sowietami a synowi, zgodnie z kanonem mitów romantycznych, kazał przekazać, że w jego życiu była inna kobieta Polska. Jedna przegrana bitwa stanowi swego rodzaju uzasadnienie dla pozostałych napisanych przez Wolskiego powieści z gatunku historii alternatywnych. Skoro Polska była poddana sowieckiemu kolonializmowi, choć nie aż tak tragicznie jak w Jednej przegranej bitwie, to powinna powrócić do swej wspaniałej przeszłości, choćby w fantastycznych scenariuszach. Nic również dziwnego, że we wszystkich przywołanych powieściach Wolskiego mężem opatrznościowym Polski jest Józef Piłsudski.

Ta postać jest również kluczowa dla Piotra Zychowicza, autora książki pt. Pakt Ribbentrop-Beck, czyli jak Polacy mogli u boku III Rzeszy pokonać Zwiazek Sowiecki. Praca ta nie jest powieścią, nie przynależy więc do literackich historii alternatywnych, a realizuje jej wariant niefabularny, dziennikarski, mocno perswazyjny i zretoryzowany. Pakt Ribbentrop-Beck należy postrzegać jako element pop-historii, zjawisko tabloidyzacji historii, czynienia z historii rozrywki, wreszcie jako histotainment ${ }^{101}$. Zychowicz równocześnie finguje jednak niektóre cechy monografii historycznej, np. obszerną bibliografię. Zychowicz, podobnie jak Wolski, zainspirował się pracami Pawła Wieczorkiewicza i rozważa scenariusz Polski sprzymierzonej z Hitlerem, zwany tutaj Realpolitik, bo: „Narody muszą podejmować wątpliwe moralnie decyzje i zawierać taktyczne sojusze z partnerami, którzy wzbudzają ich niechęć i obrzydzenie ${ }^{102 "}$.

Książka ta dokonuje restauracji mitu Polski federacyjnej, władającej Ukrainą i Litwą. Autor zadaje pytanie kluczowe, obnażające kolonialne tęsknoty pytanie:

Czy byliśmy skazani na utratę połowy terytorium, z ukochanymi Wilnem i Lwowem na czele? (...) Wszystkie te nieszczęścia, które spadły na Rzeczpospolitą i jej naro-

100 Ibidem, s. 4.

101 Por. R. A. Ansorg, Dokufiction? Living History? Histotainment? Der Archäologe im Fernsehen zwischen Reenactment und Computeranimation. Hamburg 2012; Aufklärung, Bildung, "Histotainment"?: Zeitgeschichte in Unterricht und Gesselschaft Heute. Red. M. Barricelli, J. Hornig. Frankfurt am Mein 2008; P. Lisiecki, Przeszłość ma przyszłość. „Uważam Rze Historia” 2012, nr 1; A. Szpociński, Wspótczesna kultura historyczna. „Kultura Współczesna” 2011, nr 1; N. Lemann, Literatura, historia, kultura popularna - Przestrzenie konwergencji. Wprowadzenie. „Zagadnienia Rodzajów Literackich” 2012, nr 2, s. 123-148.

102 A. Zychowicz, Pakt Ribbentrop-Beck, czyli jak Polacy mogli u boku III Rzeszy pokonać Zwiazek Sowiecki, op. cit., s. 21. 
dy... ${ }^{103}$. (...) Nie jest bowiem łatwe do zrozumienia, jak Polak młodej generacji mógłby nie tęsknić do odzyskania granic Władysława IV, jak mógłby marzyć o malutkiej Polsce Łokietka104.

Zychowicz nie godzi się na rozwiązania zaproponowane po 1918 roku, skoro:

Pod sowieckim jarzmem znajdowały się bowiem olbrzymie tereny Rzeczypospolitej. Województwa połockie, witebskie, większość mińskiego, smoleńskie, mścisławskie, spore części nowogródzkiego i brzeskolitewskiego, czernichowskie, część wołyńskiego, kijowskie, podolskie i bracławskie (nasz stan posiadania w XVII wieku). Mieliśmy więc o co się z Sowietami bić i mieliśmy pełne prawo wystąpić z hasłem wyzwolenia tych terytoriów.

Wszystko to było naszą spuścizną i o wszystko to podczas drugiej wojny światowej mogliśmy się byli upomnieć i mogliśmy o to walczyć. Ziemie te liczyły setki tysięcy kilometrów kwadratowych i zamieszkiwało je co najmniej kilkanaście milionów przedstawicieli narodów Rzeczypospolitej: Białorusinów, Ukraińców, Żydów, Rusinów, Tatarów, Karaimów i jeszcze tuzina innych. Samych Polaków mieszkało tam grubo ponad milion (oczywiście mowa o tych, którzy w 1937 roku przeżyli "operację polską" NKWD) ${ }^{105}$.

Zychowicz, mówiąc o odzyskaniu Kresów, operuje doskonale rozwiniętym dyskursem kolonialnym, w którym odnajdziemy poczucie wyższości kulturowej i ogólno-cywilizacyjnej i idące w ślad za nim poczucie misji, konieczności podjęcia „brzemienia białego człowieka” oraz odpowiedzialność za "gorsze” narody Europy. Autor jest przekonany, że polskie wojska byłyby witane na Ukrainie i Litwie z prawdziwą radością, jako wyzwoliciele spod jarzma ZSRR. W rozwijanym przez niego scenariuszu Beck i Ribbentrop ustaliliby, że "Sowiety zostaną podzielone zgodnie z kluczem historycznym ${ }^{106}{ }^{\prime \prime}$. Zaś:

Mieszkańcy Litwy, Łotwy i Estonii, którzy od blisko pięciu lat żyli pod ciężkim niemieckim butem, witali Polaków jak wyzwolicieli. Prusy zostały formalnie inkorporowane do Rzeczypospolitej, a państwa bałtyckie, po zwróceniu im przez Polskę suwerenności, dobrowolnie dołączyły do tworzonej przez Polskę, Białoruś i Ukrainę federacji. Marzenie marszałka Piłsudskiego zostało zrealizowane. Polska stała się potężna.(...). Miała się ona składać z Polski, Białorusi, Ukrainy i ewentualnie Litwy. Ten kierowany przez Polaków blok nawiązujący do potężnej Rzeczypospolitej Jagiellonów miał się stać regionalnym mocarstwem. Państwem zdolnym przeciwstawić się zakusom Sowietów i Niemców $(\ldots)^{107}$.

\footnotetext{
103 Ibidem, s. 22.

104 Ibidem, s. 58.

105 Ibidem, s. 52.

106 Ibidem, s. 16.

107 Ibidem, s. 20.
} 
Pakt Ribbentop-Beck Zychowicza jest doskonałym przykładem pisania alternatywnej historii narodu w oparciu o zadawnione urazy subalterna, dla którego najprostszym sposobem budowania nowej postzależnościowej tożsamości jest tryb przekonania o dawnej potędze i absolutnej moralnej przewagi, płynącej z „,upodobani[a] do spoglądania wstecz, ku suwerennej przeszłości, w której da się wykazać momenty chwały, gdy teraźniejszość cierpi na ich niedosyt ${ }^{108 "}$. Nic więc dziwnego, że Paul Valèry twierdził, iż historia, która od zawsze chciała być nauczycielką życia, jest $\mathrm{w}$ istocie

[...] Najniebezpieczniejszym wytworem, jaki wyprodukowała chemia intelektu. Jej właściwości są dobrze znane. Rozsnuwa ona marzenia, odurza ludy, tworzy im fałszywe wspomnienia, wyolbrzymia ich odruchy, zachowuje ich stare rany, dręczy ich w snach, prowadzi do obłędu wielkości, lub do szału prześladowania, czyni narody dokuczliwymi, pysznymi, nieznośnymi i zarozumiałymi. Historia usprawiedliwia wszystko, czego się pragnie ${ }^{109}$.

Obserwując w kulturze polskiej wyraźny trend opiewania heroicznej przeszłości, Leszek Koczanowicz zauważył, że:

Teoria postkolonialna nie powstała po to, by nadawać jednym narodom wyższą rangę niż innym, czy też po to, by spełniać marzenia konserwatystów o powrocie do jakiejś utopijnej jedności narodu zniszczonej przez podbój. Jej zasadniczym przesłaniem jest emancypacja, wyzwolenie od mitów narzuconych przez kolonizatorów, ale też własnych mitów narodowych ${ }^{110}$.

Co ciekawe, Bolesław Prus, prekursor historii alternatywnych w Polsce, w noweli pt. Zemsta111, napisanej w 1908 roku pod wpływem ustawy wywłaszczeniowej, ostrzega przed zbyt prostym i atrakcyjnym marzeniem o podążeniu ścieżką dawnego kolonizatora. Główny bohater noweli, Władysław Miller, ma szansę zrealizować marzenia o zemście na Prusakach. Indyjski jogin Ahmakara w zamian za duszę (czytelny motyw faustowski) pozwala Millerowi przez 20 lat realizować plany i daje mu „władzę i wolność szkodzenia ludziom i narodom"112. JoginSzatan pozwala Polakowi poznać przyszłość w dwóch wariantach. Nie pozwala jej jednak zmienić, co wydaje się kluczowe. W wariancie „z zemstą" Polacy otrzymują kolonię na Saharze, zmieniając ją w utopię, a to dzięki „pracy energicznej, wie-

${ }^{108}$ H. Gosk, Opowieści "skolonizowanego/kolonizatora", op. cit., s. 18-19.

109 P. Valéry, Regards sur le monde actuel. Paris 1931, s. 63-64. Cyt. za: A. F. Grabski, Dzieje historiografii. Red. R. Stobiecki. Poznań 2003, s. 716-717.

${ }^{110}$ L. Koczanowicz, Post-komunizm a kulturowe wojny. W: Kultura po przejściach. Osoby z przeszłościa, op. cit., s. 27.

${ }^{111}$ Nowela opublikowana w „Kurierze Warszawskim”. 1908, nr 1, cyt. za: http://www.pbi. edu.pl/book_reader.php?p=11516Bolesław Prus (data dostępu: 15.7. 2013).

112 Ibidem. 
dzy twórczej i cnocie". Prus powstrzymuje jednak swego bohatera przed zemstą, wybiera wariant trudniejszy, ale bardziej moralny. Opiera się diabelskiej pokusie, uznając mądrość maksymy biblijnej „Mnie zostaw zemstę - mówi Pan”. Słowa te kończą opowiadanie. Wcześniej jednak, pojawia się wyjątkowo aktualne wezwanie, korespondujące ze słowami Koczanowicza:

Nie ma co nazywać się przedmurzem chrześcijaństwa; wspominać zwycięstwa pod Grunwaldem, odsieczy wiedeńskiej, wąwozów Samosierra; miniona bowiem sława tyle jest warta, co chleb zjedzony w roku zeszłym.

Wydaje się, że odwoływanie się do mitów heroicznych i alternatywne kreowanie potęgi Polski przez niektórych twórców współczesnych historii alternatywnych jest, jak już powyżej sugerowałam, związane z dojmującym rozczarowaniem historią po 1939 roku, kiedy to Polska po raz kolejny została poddana sąsiedzkiej hegemonii. Trauma okazała się tak wielka, że „przeszłość okaz[uje] się niewyobrażalna (...) [i] pozwala się określić jako post-przeszłość113". W efekcie tym silniejsze okazują się jednak wszelkie traumy, zadawnione urazy, wstydy, upokorzenia, a w ślad za nimi -mechanizm samodeprecjacji. Taki tryb myślenia i pisania, mówiąc słowami Czesława Miłosza, powoduje iż „W cieniu Imperium (...) Pierogi jesz leniwe, zupę nic na zimno / I wiecznie upokorzony, nienawidzisz obcych ${ }^{114 "}$.

Proces post-zależnościowego „pisania narodu” nie jest zjawiskiem jednorodnym, bo i niezwykle złożony bywa wachlarz reakcji na wyjście z sytuacji długoletniego uzależnienia. Przytoczone przeze mnie powieści z gatunku historii alternatywnych realizujących model „hegemonicznej Polski” są zaś jednym z możliwych trybów powstawania "koniecznych fikcji”. Historie alternatywne, zanurzone w żywiole historii i współczesności reagują niczym sejsmograf na wszelkie drgania społecznych nastrojów, rejestrując zarówno te nostalgicznie szukające ideału w złotej, minionej przeszłości, jak i te ironicznie podejrzliwe wobec mitów i zbyt prostych ocen. Dlatego też literatura, w tym historie alternatywne, są tak znakomitym probierzem pozaliterackiej rzeczywistości historyczno-społecznej.

${ }^{113}$ R. Nycz, Wprowadzenie, "nie leczony, chroniczny pogłos”. W: Kultura po przejściach. Osoby z przeszłościq, op. cit., s. 11.

${ }^{114}$ Cz. Miłosz, Osobny zeszyt strona 29. W: Wiersze wszystkie. Kraków 2011, s. 738. 